\title{
SATE LILIT LINDUNG dan SATE KAKUL KULINER TRADISONAL LANGKA di BALI
}

\author{
Ejasa Sembiring dan Anastasia Sulistyawati \\ Email: ejasa.sembiring@pib.ac.id dan prof.sulistyawati@yahoo.com \\ POLITEKNIK INTERNASIONAL BALI
}

\begin{abstract}
Abstrak
Penelitian ini bertujuan untuk mengetahui: (1) Identifikasi dan inventarisasi mengenai sate lilit lindung dan sate kakul, (2) Cara untuk merevitalisasi lingkungan sumber hidup (alami dan hayati) bahan utama jenis sate lilit lindung dan sate kakul yang sudah langka tersebut. Jenis penelitian adalah deskriptif analitis. Pengumpulan data adalah wawancara dan studi pustaka. Teori digunakan teori revitalisasi dan pemasaran.

Hasil penelitian menunjukkan bahan utama sate lilit lindung dan sate kakul berlokasi hidup di sawah, memiliki gizi tinggi dan pembuatan berdasarkan tradisi turun temurun masyarakat Bali. Revitalisasi perlu dilakukan karena masalah habitat untuk bahan utama berupa lindung dan kakul menjadi berkurang. Revitalisasi dapat dilakukan dengan revitalisasi fisik menjaga lingkungan aslinya dan melalui pembudidayaan. Dukungan semua stakeholder dibutuhkan agar dapat meningkatkan kesadaran budaya, sehingga nantinya diharapkan juga membangkitkan keinginan menyelamatkan lingkungan sumber daya alam dan hayatinya dari tindakan yang dapat merusak.
\end{abstract}

Kata kunci: kuliner tradisional, langka, sate, Bali.

\begin{abstract}
This study aims at describing: (1) the identification and inventory of satay lilit lindung and satay kakul, (2) Obtaining a way to revitalize the environment of their living resources (natural and biological), as the main rare type of ingredients. This type of research is descriptive analytical. The data collection techniques are interviews and literature study. The theory used are the theory of revitalization and marketing.

The results showed that lindung and kakul both naturally live in the rice fields, and as food resources they contain high nutrition. The ingredients and the cooking methods of them are based on the traditional Balinese culinary. Revitalization needs to be done to protect the lindung and kakul habitats. It can be done by physical maintenance of the original environment as well as through cultivation. Support from all stakeholders is needed in order to increase the local awareness to their own culture, to generate their awareness to save the natural and biological resources.
\end{abstract}

Keywords: traditional culinary, rare, satay, Bali. 


\section{Pendahuluan}

Indonesia merupakan salah satu Negara yang menjadi sasaran jajahan. Penjajah menginginkan rempah-rempah yang ada di Indonesia, karena kualitas dari rempah-rempah Indonesia adalah salah satu yang terbaik di seluruh dunia. Salah satu alasan kenapa masakan asli Indonesia bisa diterima dan disenangi oleh warga negara lain karena masakan Indonesia diolah dengan rempah berkualitas. Kuliner Indonesia yang sangat kaya memberikan sumbangan cukup besar dalam ekonomi kreatif. Sebesar 30-40 persen pengeluaran rata-rata wisatawan dialokasikan untuk wisata kuliner. Wisata kuliner didukung oleh Kementrian Pariwisata yang menetapkan lima makanan nasional Indonesia dan Indonesia memiliki national food. Penentuan makanan nasional ini berdasarkan Forum Group Discussion (FGD) komunitas kuliner. Berikut daftar lima national food Indonesia versi Kemenpar, yaitu soto, rendang, sate, nasi goreng, dan gado-gado (https://travel.kompas.com/read/2017/04/10/171000627/ kemenpar-tetapkan-5-akanan-nasional-indonesia-ini-daftarnya).

Dari lima masakan nasional yang dibahas lebih lanjut adalah sate yang sudah terdaftar sebagai peringkat ke-14 dalam World's 50 Most Delicious Foods (50 Hidangan Paling Lezat di Dunia) melalui jajak pendapat pembaca yang digelar oleh CNN Go pada 2011. Indonesia adalah negeri asal mula sate, dan hidangan sate dikenal luas hampir di seluruh wilayah Indonesia dan dianggap sebagai masakan nasional dan salah satu hidangan terbaik Indonesia. Sate yang diketahui berasal dari Jawa, juga populer di negara-negara Asia Tenggara lainnya.

Di Indonesia, sate dapat diperoleh dari pedagang sate keliling, pedagang kaki lima di warung tepi jalan, hingga di restoran kelas atas atau restoran mewah di hotel berbintang, serta kerap disajikan dalam pesta dan kenduri. Hampir segala jenis daging dapat dibuat sate. Destinasi kuliner yang saat ini sangat terkenal hingga mancanegara salah satunya adalah 
Kuliner Tradisional Bali (KTB). Salah satu kuliner tradisonal Bali adalah sate. Sate di Bali bukan sekedar makanan, namun memiliki makna yang lebih luas dari sekedar sumber nutrisi, karena terkait dengan kepercayaan, status, prestise, setiakawan, dan ketentraman para pendukung budaya.

Dewasa ini banyak kuliner tradisional, khususnya di Bali yang sudah mulai langka. Beberapa jenis sate Bali yang kini sudah sangat langka akibat dari dampak perubahan lingkungan hidupnya, adalah: sate lilit lindung dan sate kakul. Keadaan lingkungan hidup makhluk bahan makanan tradisional Bali saat ini, menyebabkan mulai langkanya untuk ditemukan dan dinikmati. Jenis sate lilit lindung dan kakul mulai langka dari segi bahannya. Sate lilit yang merupakan salah satu varian sate asal Bali ini dapat dibuat dari daging babi, ikan, ayam, daging sapi, atau bahkan kurakura. Sate lilit dari bahan ikan yaitu ikan lindung (belut) saat ini sudah sangat langka. Awalnya lindung banyak ditemukan di lingkungan pedesaan yang masih banyak ada sawah dan masih bersih, serta alami lingkungannya baik tanah, air maupun udaranya. Dewasa ini, sawah sudah banyak menggunakan zat-zat kimia yang menyebabkan habitat lindung menjadi rusak, selain itu banyaknya sawah yang dialihfungsikan menjadi lahan perumahan, sehingga habitat lindung semakin hari semakin berkurang.

Selain sate lilit lindung, sate kakul (siput) juga mulai langka saat ini. Sate kakul mulai langka disebabkan dengan alasan yang sama mulai langkanya sate lilit lindung, yaitu lingkungan hidup kakul (siput) yang saat ini mulai rusak, sehingga populasi kakul juga semakin berkurang.

Berdasarkan latar belakang masalah di atas maka dapat dirumuskan menjadi beberapa pokok masalah, sebagai berikut: (1) Bagaimanakah identifikasi dan inventarisasi mengenai sate lilit lindung dan sate kakul? (2) Bagaimanakah cara untuk merevitalisasi lingkungan sumber hidup 
(alami dan hayati) bahan utama jenis sate lilit lindung dan sate kakul yang sudah langka tersebut?

\section{Teori dan Metode}

Teori yang digunakan untuk memecahkan pokok permasalahan adalah teori revitalisasi dan teori pemasaran. Teori revitalisasi penelitian ini adalah upaya untuk memvitalkan kembali suatu lingkungan atau habitat asli yang dulunya pernah vital hidup akan tetapi mengalami kemunduran dan degradasi. Selanjutnya teori pemasaran pariwisata adalah upaya yang dilakukan oleh organisasi pariwisata nasional dan atau badan usaha pariwisata untuk menciptakan, menyampaikan, dan mengkomunikasikan nilai-nilai unggul pariwisata (kuliner Bali) kepada calon wisatawan dengan maksud meningkatkan pertumbuhan pariwisata. Teori ini digunakan untuk membantu mengembangkan kuliner langka yang ada di Bali agar masyarakat akan berusaha untuk merevitalisasi lingkungan habitat lindung dan kakul.

Penelitian ini memakai pendekatan holistik berarti cara melihat atau memandang sesuatu sebagai suatu kesatuan yang utuh. Penelitian ini bersifat studi pustaka yaitu pengumpulan data dilakukan di perpustakaan Politeknik Internasional Bali (PIB), baik melalui buku-buku KTB dan buku-buku manajemen dalam bidang kuliner pariwisata serta ditunjang informasi yang tersedia di internet. Informasi langsung diperoleh dari wawancara dengan informan kunci dari generasi lampau yang pernah menikmati dan berpengalaman langsung memasak kuliner yang kini sudah menjadi langka tersebut.

Jenis penelitian adalah deskriptif analitis (descriptive analitic) karena penelitian ini bertujuan untuk mendapatkan gambaran dan informasi tentang potensi jenis-jenis Kuliner Tradisional Bali khususnya sate lilit lindung dan sate kakul yang sudah langka dan mengetahui permasalahan 
kendala yang dihadapinya dalam pengembangannya untuk mencari cara pemecahannya. Penelitian deskriptif analitis bertujuan untuk memeroleh secara jelas tentang suatu situasi atau keadaan tertentu yang ada di lapangan melalui pengumpulan data, dalam hal ini khususnya cara membuat kuliner yang sudah langka ini dan kaitannya dengan penyebab terjadinya keterbatasan potensi pasokan bahan alam dan hayati yang ada di daerah Bali saat ini.

\section{Pembahasan}

Pada pembahasan akan dijawab seluruh masalah yang ada dalam penulisan dan dibahas dengan lebih mendalam.

\subsection{Mengidentifikasi dan Menginventarisasi Sate Lilit Lindung dan Sate Kakul}

Kuliner Tradisional Bali sate lilit lindung (belut) dan sate kakul (siput sawah) akan dibahas secara lebih mendalam pada bagian ini.

\section{1) Sate Lilit Lindung}

Sate lilit adalah sebuah varian sate asal Bali. Lilit berarti "membungkus". Keunikan sate lilit adalah tidak dibuat dengan tusuk sate yang kecil dan tajam, namun dengan tusuk sate yang berbentuk datar dan lebar. Sate lilit ini dahulunya dibuat dengan bahan ikan, namun lama kelamaan kreasi kuliner menciptakan sate lilit yang dibuat dari bahan lain seperti daging babi, ayam, dan tuna. Sate lilit lindung adalah sate yang menggunakan daging ikan lindung (belut) sebagai bahan utamanya.

Sate lilit pada awalnya dari daerah Klungkung, lama kelamaan hidangan ini menyebar di seluruh kawasan Bali, seperti di Denpasar, Gianyar, dan Badung. Karena inilah maka sate lilit menjadi kuliner tradisional ciri khas dari Pulau Bali (https://www. 
kamerabudaya.com/2017/04/sate-lilit-makanan-khas-bali.html).

Berikut akan dibahas sate lilit dari bahan utama ikan lindung atau belut sawah.

a) Lingkungan lokasi Sate Lindung

Sate lilit dari bahan utama lindung (belut sawah) sering dibuat di lingkungan pedesaan yang masih banyak ada sawahnya dan masih bersih, serta alami lingkungannya baik tanah, air maupun udaranya. Lindung adalah istilah Bali dari belut, merupakan sekelompok ikan berbentuk mirip ular yang termasuk dalam suku Synbranchidae. Lindung termasuk anggota mahkluk bersifat pantropis (ditemukan di semua daerah tropika) termasuk Bali.

Lindung adalah jenis ikan yang boleh dikatakan tidak memiliki sirip, kecuali sirip ekor yang juga tereduksi. Ciri khas lindung yang lain adalah tidak bersisik (atau berkulit sangat licin), dapat bernapas dari udara, bukaan insang sempit, tidak memiliki kantung renang dan tulang rusuk. Mata lindung kebanyakan tidak berfungsi secara baik, bahkan jenis-jenis yang tinggal di gua-gua malahan buta.

Ukuran tubuh lindung (belut) sangat bervariasi. Monopterus indicus hanya berukuran 8,5 sentimeter, sementara belut Marmer Synbranchus marmoratus (Be Julit) diketahui dapat mencapai 1,5 meter. Belut sawah biasa dijumpai di sawah dan dijual untuk dimakan, juga ada yang dapat mencapai panjang sekitar 1 meter (dalam bahasa Bali disebut godes). Kebanyakan belut sawah tidak suka berenang dan lebih suka bersembunyi di dalam lumpur. Semua belut adalah pemangsa karnivora, mangsanya seperti ikan, katak, serangga, serta krustasea kecil. Belut merupakan jenis ikan yang bisa berubah kelamin (hermaprodit) yaitu dimasa usia muda misalnya berjenis kelamin betina, dimasa berikutnya yaitu jika sudah usia tua akan berubah menjadi berjenis kelamin jantan 
(https://pllbfmipaunlam.wordpress.com/2015/03/03/fauna-lahan-bas ah-belut/).

Sarang belut dibuat dengan cara menggali lubang seperti terowongan berliku, dalam hal ini pola sarang menyerupai huruf $U$. Binatang ini menyukai media dingin sebagai tempat tinggalnya. Apabila mengalami kenaikan temperatur air, maka belut sawah akan meninggalkan tempat tersebut. Suhu optimal saat budidaya berkisar antara 21-27 derajat celsius. Belut sawah mampu hidup di perairan dengan kandungan oksigen terlarut rendah, sedangkan ikan air tawar lainnya sudah tidak lagi mampu mempertahankan hidupnya. Oleh karena itu, tidak mengherankan jika Monopterus albus memiliki daya hidup cukup baik. Inilah salah satu kelebihannya sebagai salah satu komoditas perikanan masa depan. Tingginya daya hidup tersebut membuat potensi agribisnis budidaya ikan jenis ini semakin terbuka lebar, sehingga keberhasilan usaha budidaya lebih terjamin (http://www.tanijogonegoro. com/2013/02/budidaya-belut.html).

\section{b) Sejarah Sate Lilit Lindung}

Sejarah munculnya sate lilit lindung diduga besar memang berasal dari kreatifitas kehidupan para petani sawah di pedesaan. Masyarakat petani pedesaan di Bali setelah habis musim tanam, sambil menunggu padi tumbuh berbiak dan dewasa, para petani sering mencari belut dengan cara nyuluh (menerangi sawah) pada malam hari dengan lampu setronking sehingga lindung yang sedang keluar mencari makan terlihat jelas. Dalam keadaan lindung berada di luar lubangnya inilah para petani menangkapnya memakai sepit duri atau sepit besi. Demikian pula, bila setiap habis panen padi di sawah, para petani memiliki waktu luang untuk mencari belut di tepi sawah yang habis di panen. Hanya berbekal peralatan cangkul dan dungki (anyam kantong tempat ikan dari serat bambu), sambil 
mencangkul dekat sisi pematang dan menyusun pematang dengan tanah agar lebih kuat, sekaligus juga sambil mencari belut. Belut biasanya tinggal agak dalam bila habis panen karena sawah dalam keadaan kering. Sehingga bila dicangkul belut sulit lari dari tangkapan para petani karena tidak ada air. Sambil bekerja juga mencari belut untuk lauk pauk harian.

Hasil tangkapan belut ini biasanya dimasukkan ke dalam dungki agar tidak lari atau keluar. Sementara itu, bila tangkapan banyak bisa dibawa pulang hidup-hidup untuk dipelihara beberapa hari sampai saat dibutuhkan. Biasanya belut itu enak digoreng, atau di-plecing, namun, agar bisa dinikmati cukup lama (tahan lama) bisa dibuat menjadi sate lilit tetapi harus digoreng cukup kering, agar tidak berjamur. Agar bisa bertahan untuk dua hari, atau lebih makanya digoreng kering kemudian disimpan di tempat yang kering.

c) Kandungan Gizi

Daging belut selain rasanya enak serta banyak mengandung vitamin, juga mengandung kalori tinggi. Kandungan zat gizi setiap 100 gram berat ikan belut mengandung kalori 303 gram, protein 14 gram, lemak 27 gram, kalsium 0,02 gram, besi 0,001 gram, vitamin A 1,6 gram, vitamin B1 0,0001 gram, vitamin C 0,002 gram, serta air 58 gram (http://www.tanijogonegoro.com/2013/02/budidaya-be lut.html).

d) Bahan-bahan Sate Lilit Lindung

Terdapat bahan-bahan yang digunakan untuk membuat Sate lilit lindung, yaitu pertama bahan utama berupa daging lindung (belut) giling (atau dicincang lembut) 300 gram (terlebih dahulu isi perutnya harus dibersihkan atau dibuang. Cara membuang isi perut lindung agar tidak membahayakan tangan (terkena pisau karena licin) adalah dengan memakai lidi janur. Masukan lidi janur dari mulut lindung 
sampai ke pantatnya, kemudian lindung dipegang kuat dengan tangan kiri dan pangkal lidi dipegang tangan kanan (bagi yang kidal kebalikannya) lalu lidi diputar ke kanan sampai semua isi perut lindung terlilit di lidi baru ditarik keluar melalui mulutnya. Lidi dibersihkan lalu dari usus lindung dan dipakai lagi untuk belut yang lain. Kalau lidi sudah rusak diganti dengan lidi lain. Kalau berisi telur bisa digoreng kering dengan mengisi sedikit garam, rasanya gurih.

Bahan selanjutnya adalah kelapa parut muda enam sendok makan, garam satu sendok teh, gula pasir satu sendok teh (bagi yang suka rasa agak manis), serai 12 batang (digunakan untuk tangkai sate lilit) caranya potong sedikit pangkal serai dan potong ujungnya ukuran kira-kira 12-17 sentimeter, cuci bersih dan tiriskan agar tangkai agak kering (bisa diganti dengan batang pelepah kelapa bagian dalamnya atau bilah bambu kecil yang diraut halus).

Setelah bahan utama telah disiapkan terdapat bumbu-bumbu khususnya yang perlu dihaluskan untuk dicampurkan dalam pembuatan sate lilit lindung yaitu bawang merah enam butir, bawang putih tiga siung, cabai merah tiga buah, kencur satu ruas, jahe satu ruas, lengkuas satu ruas, kunyit satu ruas, kemiri sangrai tiga butir, merica butiran satu sampai dua sendok teh, ketumbar sangrai satu atau dua sendok teh, serai satu batang (diambil bagian putihnya).

\section{e) Cara Membuat Sate Lilit Lindung}

Langkah awal untuk membuat sate lilit lindung adalah menghaluskan bumbu halus, dapat menggunakan blender dengan sedikit air (usahakan sesedikit mungkin menggunakan air). Selanjutnya ditaruh pada mangkuk ukuran sedang, campur daging lindung giling (atau dicincang halus) dengan kelapa parut dan bumbu halus serta garam ditambah sedikit gula pasir, aduk hingga rata. Siapkan nampan datar, beri sedikit minyak, lalu panaskan. Untuk 
mengetes rasa, ambil sedikit adonan, lalu masak/panggang sebentar hingga matang, dan cicipi rasanya. Jika dirasa ada salah satu rasa yang kurang silahkan tambahkan bumbu lainnya menurut selera sendiri. Setelah itu ambil sekepal adonan, kepalkan dibuat bulat lalu dimasukan pada pangkal serai sambil sedikit dipadatkan dengan melilit pakai pijatan ibujari tangan kanan (jari tangan kiri memutar pangkal serai ke arah kiri). Setelah melekat dan terlilit baik langsung letakkan di nampan datar, dan lakukan hingga adonan semua habis.

f) Cara Memasak Sate Lilit Lindung

Siapkan tungku pembakaran yang memanjang, tuangkan arang secara merata dengan ketinggian tertentu agar tidak bersentuhan langsung dengan sate waktu dipanggang. Hidupkan tungku api pemanggangan atau pembakaran pakai umpan minyak goreng bersih dan bara dapur serta dikipas hingga semua menyala/membara. Selanjutnya masak sate dengan memanggang di atas tungku, di bolakbalik rutin di atas bara api hingga semua sisi sate lilit matang (tidak gosong), lalu angkat, dan sisihkan tempatnya. Tapi untuk sate yang akan dipakai besok hari atau lusa tidak baik dipanggang, tapi harus digoreng kering dengan minyak bersih, dan disimpan di tempat yang kering dalam wadah tertutup. Jangan menutup wadah semasih sate panas, karena bisa menjadi lembab penyebab terjadinya jamuran. Wadah penyimpanan bisa ditutup apabila sate sudah cukup dingin.

\section{g) Cara Penyajian Sate Lilit Lindung}

Sate lilit lindung ini, terasa mantap bila dihidangkan dengan nasi sela (nasi dengan campuran ketela rambat dipotong persegi empat kecil-kecil) dan sayur urap plus sambal matah khas Bali. Lebih enak lagi bisa dibuat menjadi brengkes lindung dengan bumbu bawang putih, bawang merah, minyak kelapa, kencur, pala, ketumbar, cabai, merica, jinten, jahe, bangle, terasi, garam. Setelah diaduk lalu 
dibungkus daun pisang dan digoreng sampai matang. Dengan demikian, semua akan terasa semakin lengkap, dengan lauk khas lindung. Cara membuat sambal matah pun tidak terlalu rumit, yaitu: iris bawang merah, cabe rawit merah, sereh, daun jeruk limau, tomat, tambah sedikit garam lalu aduk merata. Panaskan minyak lalu siram pada irisan sambal. Waktu penyajian sate lilit lindung yang paling tepat adalah waktu sore hari dan malam hari.

\section{2) Sate Kakul}

Siput/kakul/buit-buit termasuk dalam kelompok Operculata yang hidup di perairan dangkal yang berdasar lumpur serta ditumbuhi rerumputan air, dengan aliran air yang lamban, jernih dan bersih, misalnya sawah, rawa-rawa, pinggir danau dan pinggir sungai kecil.

Siput/keong suku viviparidae bisa memiliki tinggi cangkang sampai $40 \mathrm{~mm}$ dengan diameter 15-25 milimeter, bentuknya seperti kerucut membulat dengan warna hijau-kecoklatan atau kuning kehijauan. Puncak cangkang agak runcing, tepi cangkang menyiku tumpul pada yang muda, jumlah seluk 6-7, agak cembung, dan seluk terakhir cukup besar. Mulut membundar, tepinya bersambung, tidak melebar, umumnya hitam. Operkulum agak bulat telur, tipis, agak cekung, coklat kehitaman. Buit-buit atau kakul (siput) oleh masyarakat petani di Bali sejak lama telah sering dimanfaatkan sebagai makanan camilan atau lauk pauk (sate kakul) semusim menemani makan nasi putih (http://www.smallcrab.com/makanandan-gizi/1166-tutut-keong-sawah-yang-gurih-dan-berkhasiat).

\section{a) Lokasi Kakul}

Kakul sering dimasak masyarakat petani sawah di pedesaan Bali sebagai lauk pauk pilihan yang murah dan mudah di dapat. Masyarakat petani di pedesaan sudah sejak lama mampu 
menunjukkan kreatifitasnya dalam mewujudkan kedaulatan pangan yang berbasis bahan baku lokal, tersedia setiap musim tertentu di lingkungan sekitarnya. Salah satu yang sering menjadi pilihan adalah buit-buit atau kakul menjadi menu utama masyarakat petani bila sudah musim tanam padi usai.

Buit-buit hidup di lumpur dan air sawah serta bertelur di tepi pematang sawah atau pada pangkal tanaman padi. Waktu pasca tanam padi yang longgar ini dimanfaatkan oleh masyarakat petani untuk mencari kakul. Bisa dilakukan pakai sendok khusus terbuat dari anyaman bambu kecil bertangkai panjang. Mengambilnya cukup dari atas pematang sawah, tidak perlu turun ke lumpur. Tapi bila sawah telah tumbuh gulma maka harus disiangi (mejukut) agar tidak mengganggu tanaman padi, bisa sambil memungut kakul langsung pakai tangan dengan dungki (wadah dari anyaman bambu) di pinggang. Makhluk musiman inilah yang sering diolah dijadikan sebagai lauk pauk harian, sampai akhir musim basah, salah satunya dikenal sebagai sate kakul.

b) Sejarah Sate Kakul

Kakul bagi masyarakat kota yang tak pernah ke sawah sering dianggap sebagai hewan yang menjijikkan. Meski kakul dianggap sebagai hewan menjijikkan dan membuat geli oleh sebagian orang, namun nyatanya oleh masyarakat petani pedesaan di Bali yang setiap hari bergelut dengan kehidupan sawah, bisa diolah menjadi berbagai jenis kuliner, seperti sate kakul, be kakul base genep, be kakul base kacang. Tidak hanya di Bali dan Indonesia umumnya, hewan lunak berlendir ini ternyata sudah umum disajikan menjadi hidangan menggugah selera di beberapa negara lainnya, khususnya di kalangan masyarakat petaninya. 


\section{c) Kandungan Gizi Sate Kakul}

Kakul menyimpan kandungan gizi tinggi, yang menurut Positive Deviance Resource Centre mengandung kandungan protein 12\%, kalsium $217 \mathrm{mg}$, rendah kolesterol, 81 gram air dalam 100 gram keong sawah, dan sisanya mengandung energi, protein, kalsium, karbohidrat, dan phosfor. Siput sawah ini juga memiliki kandungan vitamin cukup tinggi, dengan dominasi vitamin $\mathrm{A}, \mathrm{E}$, niacin dan folat, di samping juga mengandung zat gizi makronutrien berupa protein dalam kadar yang cukup tinggi pada tubuhnya.

Dengan berbagai kandungannya kakul dapat menurunkan tensi darah bagi yang memiliki hypertensi. bahkan bagi yang mempunyai tekanan darah rendah juga dapat diperbolehkan mengkonsumsi sate kakul dengan batas tertentu (http://resephariini.com/resep-sate-kakulpedas-khas-bali/). Berat daging satu ekor siput sawah dewasa dapat mencapai 4-5 gram. Selain makronutrien, tubuh kakul juga mengandung mikronutrien berupa mineral, terutama kalsium yang sangat dibutuhkan oleh manusia. Dengan pengelolaan yang tepat, siput dapat dijadikan sumber protein hewani bermutu dengan harga yang jauh lebih murah daripada daging (https://id.wikipedia.org/ wiki/Keong_sawah).

\section{d) Bahan dan Bumbu Sate Kakul}

Bahan Sate kakul untuk bisa dikomsumsi sekitar kurang lebih untuk empat sampai enam (orang) adalah kakul (dari sawah) setengah $\mathrm{kg}$, dua batang serai, satu sendok makan air asam jawa, setengah sendok makan garam, $500 \mathrm{ml}$ air, dan 30 tusuk sate. Bumbu Sate Kakul adalah bawang merah enam butir, dua siung bawang putih, dua centimeter jahe, satu sentimeter kencur, dua butir kemiri sangrai, satu sendok teh terasi goreng, dan garam secukupnya. Bumbu yang diperlukan untuk bahan saus sate kakul adalah empat siung bawang 
putih dipotong-potong, tiga buah cabai merah dipotong-potong, tiga buah cabai rawit merah dipotong-potong, 100 gram kacang tanah goreng dihaluskan, 50 gram kelapa muda parut kasar disangrai dan dihaluskan, satu setengah sendok makan kecap manis, $200 \mathrm{ml}$ air panas, satu sendok teh garam, dan satu sendok makan minyak untuk menumis (http://widhiaanugrah.com/ resep-membuat-sate-kakulpedas-khas-bali-spesial-mantap/).

e) Cara Membuat Sate Kakul

Langkah awal untuk membuat sate kakul adalah rebus kakul bersama serai, air asam jawa, dan garam hingga mendidih, angkat lalu tiriskan. Selanjutnya menghaluskan semua bumbu halus, dapat menggunakan blender ditambahkan sedikit air. Selanjutnya sisihkan dapat ditaruh pada mangkuk.

Bersihkan kakul dengan air lalu potong pantat cangkangnya agar berlubang, kemudian cuci kembali dengan air bersih. Pemotongan pantat cangkang kakul berguna untuk memudahkan mengeluarkan isinya (http:// jukut-ares.blogspot.co.id/2013/03/jukut-ares-khasbali.html). Setelah isi sudah dikeluarkan, campurkan kakul dengan bumbu halus hingga merata di setiap sisinya. Cicipi sedikit untuk mengetahui apakah ada bumbu yang kurang agar bisa ditambahkan.

f) Cara Memasak Sate Kakul

Setelah kakul dibalurkan dengan bumbu harus dengan rata hingga meresap, selanjutnya tusuk-tusuk kakul dengan menggunakan tusukan sate, lalu bakar di atas bara hingga matang. Cara membuat saus untuk sate kakul adalah tumis bawang putih, cabai merah, dan cabai rawit hingga harum. angkat, haluskan. Tambahkan kacang tanah, kelapa parut, dan kecap manis, lalu aduk kembali hingga rata. Masukkan air dan garam, aduk kembali hingga matang dan bumbu tercampur dengan rata. 
g) Cara Penyajian

Siapkan piring saji. Tata Sate kakul di tas piring dan siap disajikan bersama saus atau sambal kacang pedasnya. Sate kakul akan lebih nikmat bila disantap bersama dengan jukut ares. Sate kakul dapat disantap bersama dengan nasi panas ataupun lontong, disesuaikan dengan selera. Rasanya akan sedikit kenyal sehingga memiliki cita rasa tersendiri bagi orang yang tidak biasa memakan kakul. Waktu penyajian sate kakul paling terasa nikmat adalah waktu siang dan sore hari, dalam keadaan masih hangat. Tubuh akan terasa panas saat memakannya karena kandungan gizi yang dimilikinya.

\subsection{Revitalisasi Lingkungan Sumber Hidup Bahan Utama Sate Lilit Lindung dan Sate Kakul.}

Cara untuk melindungi lingkungan sumber hidup bahan utama jenis Kuliner Tradisional Bali yang langka adalah dengan melakukan budidaya. Budidaya ikan untuk bahan lokal utama Kuliner Tradisional Bali harus dilakukan agar kekayaan Kuliner Tradisional Bali dapat terus dinikmati dan tidak punah. Karena Kuliner Tradisional Bali, seperti yang disebutkan di atas merupakan salah satu kebudayaan Bali yang perlu untuk dilestarikan dan terus dipertahankan.

1) Budidaya Lindung

Pesatnya perkembangan pembangunan permukiman dan para petani yang lebih banyak menggunakan bahan kimia dan pestisida dalam merawat tanaman padi di sawah telah mengancam populasi dari lindung secara drastis. Bahkan di area sawah tertentu sudah diambang kepunahan. Mengingat dewasa ini sulitnya mencari lindung (belut) di sawah, maka ada baiknya dilakukan budidaya belut di tempat sendiri. 
Belut biasanya dibudidayakan dalam kolam lumpur seperti di habitat aslinya di sawah. Namun perkembangan penelitian budidaya belut menunjukkan bahwa belut pun bisa di budidayakan tanpa lumpur. Beberapa faktor-faktor utama yang harus diperhatikan dalam budidaya belut di air bersih, antara lain adalah air, pakan, bibit, dan kepadatan. Pertama, air, dalam budidaya belut di air bersih, air adalah faktor utama yang sangat berpengaruh pada perkembangan belut. Air yang layak digunakan dalam budidaya belut di air bersih adalah air yang jernih, memiliki suhu antara $25-28^{\circ} \mathrm{C}$, air yang tidak mengandung zat-zat kimia berbahaya.

Kedua pakan, berikan pakan secukup mungkin, jangan kekurangan atau berlebihan, jika dalam pemberian pakan pada belut terlalu banyak bisa mengakibatkan air cepat kotor (karena sisa makanan) dan bisa mengakibatkan efek kurang baik pada belut dan kalau kekurangan makanan menimbulkan sifat kanibalisme pada belut. Makanan belut antara lain cacing lor, cacing merah, cacing lumbricus, ikan cere, ikan cithol, ikan guppy, anakan ikan mas, berudu (kecebong), lambung katak, keong mas/sawah, dan ulat hongkong.

Ketiga, bibit, pemilihan bibit belut berkualitas adalah salah satu faktor penting dalam menentukan keberhasilan budi daya belut. Bibit yang paling bagus bersal dari budidaya karena ukuran seragam dan jarang terkena penyakit. Belut yang ditangkap dengan cara alami menggunakan perangkap, seperti bubu, merupakan bibit yang cukup baik karena tidak mengalami perlakuan yang menurunkan kualitasnya, kalau disetrum tidak termasuk bibit berkualitas. Keempat, kepadatan (volume), kepadatan penebaran bibit dalam pembesaran jenis ikan sangatlah mempengaruhi pada perkembangan pertumbuhan dan tingkat kematian. Metode pembesaran belut di 
media air bersih sangat berbeda dengan penebaran bibit jenis-jenis ikan yang lainnya, kepadatan penebaran bibit belut sangat berperan penting pada pertumbuhan dan tingkat kematian. Kepadatan penebaran bibit belut untuk pertumbuhan, tergantung dalam proses pemberian pakan dan untuk tingkat kematian justru bisa meminimalkannya.

Tempat yang dapat digunakan untuk budidaya belut, yaitu tempat yang memiliki air bersih tanpa lumpur di antaranya: kolam permanen (bak semen), bak plastik, tong (drum). Dalam budidaya belut dengan menggunakan media lumpur dalam tempat $5 \times 5$ meter, hanya bisa dibuat untuk satu kolam saja berbeda dengan budidaya belut di air bersih dengan wadah dan ruangan $5 \times 5$ meter, bisa dikembangkanya tiga kali lipat dari wadah budidaya itu sendiri, karena budidaya air bersih hanya memerlukan ketinggian air 30 sentimeter, maka tempat budidaya ditingkat menjadi tiga susun (http://hobbysatwa.blogspot.co.id/2013/01/teknik-budidaya-belut-diair-tanpa.html).

\section{2) Budidaya Kakul}

Kakul dan buit-buit (siput sawah) kini mulai populer sebagai salah satu pilihan menu kuliner, karena bisa diolah ke dalam berbagai jenis menu, bisa dirajang dengan basa gede dan parutan kelapa, dijadikan sayur kuah sebagai campuran ares atau roroban (santan) dan disate. Sebagai hewan yang tumbuh musiman (pada musim padi sawah basah), maka tidak menjamin adanya keteraturan pasokan bahan baku kakul. Oleh karena itu, hal ini membuka sebuah peluang usaha yaitu Budidaya Siput Sawah agar dapat memenuhi tuntutan permintaan pasar cukup besar dan tidak pernah kekurangan stok dagangan. Budidaya kakul cukup mudah dan tidak butuh persiapan rumit. Caranya adalah dengan menyiapkan kolam pemeliharaan 
seperti habitat asli di alam dengan air mengalir untuk menjaga kualitas air tempat siput ini hidup dan berkembang biak. Berikan bahan makanan berupa dahan, daun, dan ranting tanaman sebagai tempat berlindung dan menempelkan telur.

\section{Penutup}

Berdasarkan pembahasan di atas dapat diketahui bahwa mulai langkanya Kuliner Tradisional Bali seperti sate lilit lindung dan sate kakul adalah karena masalah lingkungan yang mulai banyak menggunakan zatzat kimia dan mulai banyaknya sawah yang dijual dan dijadikan kawasan perumahan, sehingga habitat untuk hewan yang menjadi bahan utama Kuliner Tradisional Bali berupa lindung dan kakul menjadi berkurang.

Sate lilit lindung dan sate kakul merupakan beberapa kuliner Bali yang perlu untuk dikembangkan. Pengembangan dapat membantu menambah jajaran wisata kuliner yang dapat ditawarkan kepada para wisatawan asing. Selain itu, sate lilit lindung dan sate kakul harus tetap dilestarikan agak generasi muda lokal juga dapat mengenal masakan kuliner tradisionalnya.

Dukungan semua stakeholder dibutuhkan agar dapat meningkatkan kesadaran budaya para pendukung budaya tentang tinggginya nilai budaya yang terkandung dari kuliner tradisinya. Nantinya diharapkan juga akan membangkitkan sifat kreativitas mereka dalam menyelamatkan lingkungan sumber daya alam dan hayatinya dari tindakan yang dapat merusak dan membayakan keberlangsungan daya lenting dari kelestarian lingkungannya, melalui proses budidaya perikanan ataupun lingkungannya secara profesional. 


\section{Daftar Pustaka}

Ariani, Risa Panti. 2017. Mengenal Kuliner Bali. Jakarta: Rajawali Pers, PT. Raja Grafindo Persada.

Black, James A. dan Dean J. Champion. 1999. Metode dan Masalah Sosial. Bandung: Refika Aditama.

Cohen, E., dan Avieli, N. 2004. "Food in Tourism: Attraction and Ompediment". Annals of Tourisme Research. Vol 31 (4), hlm. 597-617.

Remen, I Ketut. 1987. Olah-olahan Paebatan Bali. Tanpa penerbit.

Sudiara, Putu Bagus. 1999. Tata Boga. Jakarta: Depdikbud.

Surayin, Ida Ayu. 2007. Masakan Bali. Surabaya: Paramita.

Susilo, Edi. 2010. Dinamika Struktur Sosial Dalam Ekosistem Pesisir. Malang:

Universitas Brawijaya Press.

Swastha, Basu. 1979. Asas-Asas Marketing. Yogyakarta: Liberty Offset.

Wahab, S. 1992. Manajemen Kepariwisataan. Jakarta: Pramadya Paramita.

Wrasiati, Luh Putu, Wijaya, I Made Anom Sutrisna, Suter, I Ketut, Wiranatha,

A.A. Putu Suryawan. 2017. Kuliner Tradisional Bali (Balinese Traditional Culinary). Denpasar: Udayana University Press.

Yoeti, Oka. 1990. Pengantar Ilmu Pariwisata. Bandung: Angkasa.

\section{Informan:}

1. Nama : I Wayan Sabeh

Alamat : Lingkungan Tengah, Desa Adat Lukluk, Mengwi, Badung, Bali

Umur : 78 tahun

2. Nama : Made Kesiar

Alamat : Lingkungan Badung, Desa Adat Lukluk, Mengwi, Badung, Bali

Umur : 76 tahun

3. Nama : Ni Nyoman Pineh

Alamat : Lingkungan Badung, Desa Adat Lukluk, Mengwi, Badung, Bali

Umur : : 70 tahun

4. Nama : Wayan Kariawan

Alamat : Lingkungan Badung, Desa Adat Lukluk, Mengwi, Badung, Bali

Umur : 54 tahun

\section{Studi Internet:}

Anggraini, Shabrina. 2017. Sate Lilit Hidangan Istimewa Masyarakat Bali. (serial online). [cited 2017 Juli. 25]. Available from URL: https://belang a.id/sate-lilit-bali-hidangan-istimewa/.

Anonim. 2013. Budidaya belut. (serial online). [cited 2017 May. 15]. Available from URL: http://www.tanijogonegoro.com/2013/02/budidayabelut.html.

Anonim. 2013. Teknik Budidaya Belut di Air Tanpa Lumpur (serial online). [cited 2017 Juni. 19]. Available from URL: http://hobbysatwa. blogspot.co.id/2013/01/teknik-budidaya-belut-di-air-tanpa.html. 
Anonim. 2016. Keistimewaan Warisan Kuliner Sate Lilit Khas Bali. (serial online). [cited 2017 Juli. 25]. Available from URL: http://piadacoz. com/keistimewaan-warisan-kuliner-sate-lilit-khas-bali/.

Anonim. 2017. Bisnis Traveling. (serial online). [cited 2017 Oktober. 12]. Available from URL: http://traveling.bisnis.com/.

Anonim. 2017. Resep Sate Kakul Pedas Khas Bali. (serial online). [cited 2017 Juli. 25]. Available from URL: http://resephariini.com/resep-sate-kakulpedas-khas-bali/.

Anugrah, Widhia. 2017. Resep Membuat Sate Kakul Pedas Khas Bali Spesial Mantap. (serial online). [cited 2017 Juli. 25]. Available from URL: http://widhiaanugrah.com/resep-membuat-sate-kakul-pedas-khas-balispesial-mantap/.

Araminta, Bertha. 2016. Kisah Unik Sate Lilit. (serial online). [cited 2017 Juli. 25]. Available from URL: http://berthaaraminta.blogspot.com/2016/11/ kisah-sate-lilit-khas-bali.html.

Arudam, Riyanto. 2015. Pengertian Kuliner. (serial online). [cited 2017 May. 14]. Available from URL: https://www.kanalinfo.web.id/2015/07/peng ertian-kuliner.html.

Fhirdaus, Bondan. 2013. Pengertian Kuliner. (serial online). [cited 2017 May. 14]. Available from URL: http://andanfhirdaus.blogspot.co.id/2013/01/ pengertian-kuliner-kuliner-adalah-hasil.html.

Kamerabudaya. 2017. Sate Lilit, Makanan Khas Bali. (serial online). [cited 2017 Juli. 25]. Available from URL: https://www.kamerabudaya.com/2017/0 4/sate-lilit-makanan-khas-bali.html.

Milasari. 2017. Sate Lilit Makanan Khas Bali. (serial online). [cited 2017 Juli. 25]. Available from URL: https://balikami.com/sate-lilit-makanan-khas-bali.

Prameswari, Anggita. 2013. Pengertian Kuliner. (serial online). [cited 2017 May. 14]. Available from URL: http://prameswarianggita.blogspot.co.id/p/ pengertian-kuliner-kuliner-adalah-suatu_6615.html.

Ramadhansyah, Wahyu. 2015. Pengenalan Lingkungan Lahan Basah. (serial online). [cited 2017 May. 15]. Available from URL: https://pllbfmipaun lam.wordpress.com/2015/03/03/fauna-lah an-basah-belut/.

Senja, Anggita Muslimah Maulidya Prahara. 2017. Kemenpar Tetapkan 5 Makanan Nasional Indonesia, Ini Daftarnya. (serial online). [cited 2017 Juli. 25]. Available from URL: https://travel.kompas.com/read/2017/04/ 10/ 171000627/kemenpar-tetapkan-5-makanan-nasional-indonesia-inidaftarnya.

Tutut. Keong Sawah Yang Gurih dan Berkhasiat. (serial online). [cited 2017 May. 15]. Available from URL: http://www.smallcrab.com/makanan-dangizi/1166-tutut-keong-sawah-yang-gurih-dan-berkhasiat.

Wikipedia. 2014. Budi Daya Perairan. (serial online). [cited 2017 Juli. 3]. Available from URL: https://id.wikipedia.org/wiki/Budi_daya_perairan.

Wikipedia. 2016. Keong Sawah. (serial online). [cited 2017 Juli. 3]. Available from URL: https://id.wikipedia.org/wiki/Keong_sawah.

Wikipedia. 2017. Budi Daya. (serial online). [cited 2017 Juli. 3]. Available from URL: https://id.wikipedia.org/wiki/Budi_daya.

Wikipedia. 2017. Sate Lilit. (serial online). [cited 2017 Juli. 25]. Available from URL: https://id.wikipedia.org/wiki/Sate_lilit. 
Wikipedia. 2017. Sate. (serial online). [cited 2017 Juli. 25]. Available from URL: https://id.wikipedia.org/wiki/Sate.

\section{Profil Penulis}

Dr.Drs. Ejasa Sembiring, M.Si lahir di Kabanjahe, Tanah Karo Sumatera Utara pada 28 Agustus 1962. Menyelesaikan Pendidikan S1 pada Fakultas Ilmu Pendidikan, Jurusan Psikologi Pendidikan dan Konseling, Universitas Kristen Indonesia tahun 1988. Kemudian melanjutkan studinya ke Program S2 Bidang Psikologi di Universitas Indonesia tahun 1994. Program studi selanjutnya adalah Program S3 Bidang Psikologi, Psikologi Industri dan Organisasi di Universitas "YAI" Persada Indonesia Jakarta tahun 2014. Memiliki pengalaman kerja di bidang psikologi, perhotelan, dan pendidikan pariwisata.

Prof.Dr.Ir. A. Sulistyawati, M.S.,M.M.,M.Mis.,D.Th.,Ph.D.,D.Ag (c) memperoleh gelar BAE, Bidang Arsitektur di Universitas Udayana (UNUD) pada tahun 1971. Melanjutkan pendidikan S1 Bidang Arsitektur di UNUD dan ITS pada tahun 1980. S2 Bidang Ilmu Lingkungan dan Ekologi Manusia di Universitas Indonesia tahun 1989, Program S3 Arsitektur di Oxford Brookes-UK pada tahun 1995, Program S2 Manajeman pada tahun 2000 di Sekolah Tinggi Ilmu Ekonomi Widya Jayakarta, Jakarta, Program S2 (2010) dan S3 (2013) Bidang Agama Kristen pada STTII Yogyakarta, Program S3 Bidang Pariwisata di UNUD dan selesai tahun 2017, terakhir adalah sedang menempuh Program S3 Bidang Agama Hindu di IHDN Denpasar. Jabatan pengajar yang dimiliki adalah Guru Besar Arsitektur, Fakultas Teknik UNUD tahun 2000, dan menjadi dosen di bidang Kajian Budaya (1996-2010). Memiliki 15 karya yang telah dipublikasikan. Sejak 2017 sampai sekarang menjabat sebagai Direktur Politeknik Internasional Bali, Tanah Lot, Tabanan. 